\title{
AC 2009-972: PLAIN ADVICE FOR NEW ENGINEERING FACULTY ON HOW TO MANAGE CLASSES AND MOTIVATE STUDENTS
}

\section{Seamus Freyne, Manhattan College}

An ASEE member since 2003, Seamus Freyne is an assistant professor of civil engineering at Manhattan College in New York City. His research interests include concrete materials, sustainability, and ethics.

\section{Micah Hale, University of Arkansas}

W. Micah Hale is an associate professor at the University of Arkansas where he teaches courses in civil engineering materials and concrete design. In addition to his teaching interests, he also conducts research in the areas of concrete materials and structures.

\section{Stephan Durham, University of Colorado, Denver}

Stephan Durham is an assistant professor of civil engineering at the University of Colorado at Denver. His research interests include pervious concrete, concrete in wastewater applications, and innovative highway construction materials. 


\section{Plain Advice For New Engineering Faculty On How To Manage Classes and Motivate Students}

\section{Introduction}

To be a new engineering faculty member is to have a very tough job. In most cases, you just finished your dissertation after several years of sweat and toil, and suddenly, with hardly any pause, you find yourself in a new place with new colleagues and huge new demands on your time. In addition to precipitous research requirements, you have new courses to teach, and you may not have taught much previously. Students pay increasingly hefty amounts and they rightfully trust you to impart knowledge and skills and guide them into gainful employment. All these expectations are enough to cause anyone unwanted stress. How will you do it? In this article, the authors, fairly new to academia themselves, share some simple advice on how to manage a class as a whole, motivate students individually, and be efficient with your time.

\section{Plan Your Courses}

Design your courses to give students an appropriately broad command of all topics. Do not give one topic excessive depth at the expense of other topics. Try to address the topics found on the Fundamentals of Engineering (FE) exam. Add value to each class period. ${ }^{1}$ Be decisive, confident, and knowledgeable on the subject being taught. ${ }^{2}$

Design assignments, projects, and exams to be both rigorous and fair. ${ }^{3}$ Gear the lectures to the assignments, and gear the assignments to the exams. Keep the audience in mind, and be mindful of the scholastic background and maturity of the students in your course. ${ }^{2}$ Do not make the course easy in an attempt to please students, as a course without some difficulty is ultimately a disservice to the students and yourself.

Problems can arise when there are multiple sections of the same course taught by different faculty members. In these situations, try to be consistent across all sections. Meet with the faculty who will teach the course and come to a general agreement on the syllabus. Choose the same textbook. Give roughly the same assignments, projects, and exams. As you can guess, your students will complain if they think the workload in your course is too heavy, and students in other sections will complain if they detect the workload in your course is too light. You will hear about it, the other faculty will hear about it, and so will the department head.

What happens if you meet resistance when trying to reach some consensus on the syllabus? Say you want to update the course with some new topics or experiments, but other faculty want to teach the course as it has previously been taught. Unless you can convince the other faculty of the merits of the proposed changes and promise to help with preparation of the new lectures, then you should just follow the status quo. Be patient, as eventually you will likely be able to revise the course without making waves. In the meantime, pour your creative efforts into your research. 


\section{Set the Tone}

Professors can undeniably influence students' success. It all starts on the first day of class; this is when you establish the tone. Tell students that you will do your best to make the topic enjoyable, and hopefully they will smile and laugh in class at least once every day. But also lay down the rules. Be explicit about your policies and expectations. You should cultivate a casual atmosphere, but you should not allow students to be disruptive or act unprofessionally. Here are some suggestions about policies and expectations you may want to include in your syllabus.

- Try your best; you owe this much to yourself and to those who support your education

- Work consistently and smartly

- Have a positive attitude

- Participate in class discussions

- Ask questions if you don't understand

- Be respectful and supportive of others

- Do not eat in class

- Put away all communication and music devices

- Bring calculators to class

- Come to class regularly and on time

- Those who arrive to class up to ten minutes late will be counted as tardy

- Those who arrive to class more than ten minutes late will be counted as absent

- If you miss class, ask a friend to give you the lecture material

- Work must be turned in on time to receive full credit; late work will be penalized $30 \%$ immediately and an additional $10 \%$ each following day

- Missed exams can only be made up with a suitable excuse

- Questions about scores must be settled within one week of when the work is returned

To enforce some of these policies and expectations, especially the rules about attendance and commitment, you may want to include a citizenship component that will count as much as $10 \%$ toward a student's final grade.

As you insist your students arrive on time and be prepared, you must do the same. ${ }^{4}$ Your conduct will speak volumes about your values. Also, use the full class time, but do not keep the class long. Students may have just ten minutes to hustle across campus to begin the next class.

Use extra credit purposefully, but sparingly. You may want to award extra credit to those students who join a professional society, such as the American Society of Civil Engineers (ASCE), and become active on various teams, such as concrete canoe and steel bridge. To encourage students to experience campus life to the fullest, you may also give extra credit to students who attend social, athletic, artistic, cultural, or religious events. Extra credit can also be awarded to students who perform service projects.

The syllabus is a contract between you and the students. It should define the goals of the course and establish a sense of routine. Students, like everyone else, find comfort in routines. ${ }^{5}$ 


\section{Use a Variety of Teaching Methods}

Students learn in different ways, so supplement the mainstay lectures with some alternative teaching techniques. ${ }^{6}$ Be innovative, and recognize some ideas will work, and some will not. ${ }^{4}$ The goal is to make students active participants in the learning process. Assign both individual work and group projects. Limit your use of PowerPoint presentations. ${ }^{1}$ Games or contests can be an effective way to review before exams. One idea is to divide the class into two teams to play "academic baseball.".

Do not rush to get through the material. ${ }^{6}$ Try to find a pace that is not too fast and not too slow. If the class is struggling with a subject, you may want to make adjustments to the schedule. ${ }^{2}$

Emphasize example problems in class and spend less time on theory. Point students to the textbook to learn the mathematical derivations. ${ }^{2}$ Use physical models to demonstrate theoretical concepts. ${ }^{8}$ Incorporate your research interests into lectures to convey a sense of excitement. ${ }^{6}$

Assess the new teaching methods you try, and publish an article about it. ${ }^{9}$ Then you might attend the annual American Society for Engineering Education (ASEE) conference and exposition and learn additional teaching techniques.

\section{Invite Guest Lectures}

Since you spend most of your days on campus, you cannot possibly keep up with all the happenings in the "real world," so invite an expert to give a guest lecture. Sometimes students need to hear from someone who works in industry or government to prove to them the importance of education. Students are motivated to learn what they perceive is relevant to their future ambitions. ${ }^{2}$ They need to know that what are trying to learn has applications, and can someday bring them a healthy salary. You may not have to look far to find someone to talk to your class. Nearby alumni are usually plentiful and happy to help. Your students may have parents that work in the engineering field.

Sometimes you may also ask groups of students to give guest lectures on topics they had time to research. To keep up with current events, ask students to give weekly summaries of the news in the field. The best way to learn is to teach.

As you grade exams, identify students who did the problems correctly and, when you return the exams, ask those individuals to put the solutions up on the board. You can catch a few minutes of rest, and students who did well on the exam will have a chance to shine. Some students may decline due to shyness, but most students will eagerly accept the opportunity. Also, when students see peers up at the board with the solutions, they will likely be convinced that the exam was not unreasonable, they will be less apt to complain, and they may be motivated to improve their performance on the next exam. 


\section{Have Students Grade Assignments}

Your time is valuable, and you cannot afford to spend it unwisely. Use the support system around you. When appropriate, delegate some work to teaching assistants and staff. Most likely you will need to carefully grade projects and exams yourself. But do not spend too much effort on weekly assignments; grading assignments can consume an overwhelming amount of time. One way to handle this is to have the students grade their own assignments. Develop a rubric like the one here, with ten points as the maximum. On the day an assignment is due, provide students with the answers and ask them to give themselves a grade. You will find most students to be honest, and also appreciative that the grading criteria are transparent. Collect the assignments, record the grades, and promptly return the assignments the next class period.

\section{Grading Criteria For Assignments}

\begin{tabular}{|c|c|c|c|}
\hline & Excellent & Satisfactory & Needs Improvement \\
\hline Organization & $\begin{array}{l}\text { Name, date, course, and } \\
\text { assignment number are } \\
\text { at the top of every sheet. } \\
\text { Paper is standard size. } \\
\text { Work is on one side of } \\
\text { sheets only. All sheets } \\
\text { are attached. } \\
\text { Points: } 1\end{array}$ & & $\begin{array}{l}\text { Some information is } \\
\text { absent, or paper is } \\
\text { unusual size, or work is } \\
\text { on both sides of the } \\
\text { sheets, or the sheets are } \\
\text { not attached. } \\
\text { Points: } 0\end{array}$ \\
\hline Neatness & $\begin{array}{l}\text { Professional quality } \\
\text { presentation. Easy to } \\
\text { read. The majority of } \\
\text { the work is done with } \\
\text { pencil and without any } \\
\text { smudges or scribbles. } \\
\text { Sketches are precise. } \\
\text { Points: } 1\end{array}$ & & $\begin{array}{l}\text { Sheets are rumpled like } \\
\text { they spent time at the } \\
\text { bottom of a backpack, or } \\
\text { they have coffee spills. } \\
\text { Work is sloppy or done } \\
\text { with a pen. } \\
\text { Points: } 0\end{array}$ \\
\hline Method & $\begin{array}{l}\text { Every problem begins } \\
\text { with a statement of what } \\
\text { is given and what is } \\
\text { required and a sketch. } \\
\text { The solutions contain } \\
\text { formulas and } \\
\text { calculations. Answers } \\
\text { are clearly identified and } \\
\text { have units. } \\
\text { Points: } 1\end{array}$ & & $\begin{array}{l}\text { Someone may have } \\
\text { difficulty trying to } \\
\text { follow the work because } \\
\text { it does not contain } \\
\text { enough information. } \\
\text { The problems lack } \\
\text { sketches. } \\
\text { Points: } 0\end{array}$ \\
\hline Content & $\begin{array}{l}\text { All problems are done } \\
\text { fully and correctly. } \\
\text { Points: } 7\end{array}$ & $\begin{array}{l}\text { All problems are } \\
\text { attempted and most are } \\
\text { done fully and correctly. } \\
\text { Points: } 4 \text { to } 6\end{array}$ & $\begin{array}{l}\text { Most problems are } \\
\text { attempted, and some are } \\
\text { done fully and correctly. } \\
\text { Points: } 1 \text { to } 3\end{array}$ \\
\hline
\end{tabular}




\section{Demonstrate a Genuine Interest in Students' Lives}

Students will appreciate your availability and approachability. Be at your office when you should be at your office. Welcome students into your office even when you are busy. Besides a visit to your office, students may contact you in a multitude of ways. Kindly respond these inquiries within one day. Be patient with students, and recall how you were timid and insecure around your professors when you were a student. Many students merely want confirmation that they are working hard.

Quickly learn the students' names. One easy way to do this is to have students make name placards and then take pictures on the first day of classes. Keep the pictures too, as students may contact you in the years ahead, and then you can put a face to the name.

Balance criticism with encouragement and praise. With too much criticism, students may lose heart, or just tune you out. Almost everyone thrives on praise, and just a few words can go a long way.

Express an interest in the students' lives. Take a few minutes to chat with students in the halls. Share job leads with students and be happy to write letters of recommendation. When students return to campus in the fall, ask them about their summer internships. Quite simply, if students know you like them and care about them, they will be much more likely to try hard in your class so they do not disappoint you. Your course evaluations will also improve.

\section{Seek Advice from Colleagues}

As someone new to academia, you have invaluable resources around you in your colleagues. These colleagues will almost certainly be glad to help you navigate through the turbulent seas of tenure. They have taught many courses. They have been around students many years, and in some cases they have taught the parents of the current students. They are savvy in the mysterious and sometimes frightful ways of campus politics. Never miss a chance to receive guidance from your colleagues. Walk down the hall every day and where you find an open doorway, say hi. Plan regular activities with a few colleagues away from the office such as a casual morning run or a weekly lunch.

Improve your teaching skills. Almost every university has various kinds of colloquiums. The ASCE supports a workshop called Excellence in Civil Engineering Education (ExCEEd), where new professors spend an intensive six days learning the latest teaching methods. ${ }^{10}$ Ask a colleague to attend one of your classes and provide some suggestions. Attend the lectures of other good teachers, even those outside your department. ${ }^{6}$ Read and reflect on your course evaluations, as some of the students' comments may prove to be very insightful. ${ }^{2}$

Though the hurdle to tenure may be high, you should feel some comfort in the fact that you represent a substantial investment on the part of the department and university, and it is in everyone's interest that you are successful, with many productive years ahead. 


\section{Be Assertive}

To be successful, you must be assertive. In department meetings, though you may feel you should be submissive to those with seniority, speak your mind when you need to. Everyone will welcome the honest and fresh perspective that you bring.

Request a teaching schedule that allows you time to do research. Try to have all your courses on Monday, Wednesday, and Friday, or Tuesday and Thursday. You should have at least one weekday free of courses so you can turn your full efforts to research. On such days, find a place where you can work on research without undue distraction. Head to the lab or field. Do not hesitate to shut your office door, or retreat to a quiet desk at the library. Work at home.

Claim a specific course that you can regularly teach. ${ }^{9}$ It is a substantial time investment to teach a course the first time, and you will become efficient with subsequent offerings. Also, ask to teach one upper level course so you can identify potential graduate students to help with your research.

The love of teaching is why most people accept a job in academia, and new professors have a propensity to spend an exorbitant amount of time preparing course materials. But you must set priorities. Do not allow the courses and students to totally pull you away from the other job requirements, namely research, and, of course, your personal life too. ${ }^{2,5,11}$

\section{Bibliography}

${ }^{1}$ Rockland, R. H., "Effective Teaching Training for New Faculty through Analysis of a Student Evaluation Form," Proceedings of the American Society for Engineering Education Annual Conference and Exposition, 2002

${ }^{2}$ Miller, A., "Expectations 101: The Course New Faculty Must Not Fail," Proceedings of the American Society for Engineering Education Annual Conference and Exposition, 2003

${ }^{3}$ Brent, R., Felder, R., and Rajala, S., "Preparing New Faculty Members to be Successful: A Radical Concept," Proceedings of the American Society for Engineering Education Annual Conference and Exposition, 2006

${ }^{4}$ Soukup, R. J., "Guidance for New Faculty," Proceedings of the American Society for Engineering Education Annual Conference and Exposition, 1999

${ }^{5}$ Minerick, A. R. and Keith, J. M., "Culture Shock: Acclimating as a New Faculty Member," Proceedings of the American Society for Engineering Education Annual Conference and Exposition, 2005

${ }^{6}$ Brent, R., and Felder, R. M., "Helping New Faculty Get Off to a Good Start," Proceedings of the American Society for Engineering Education Annual Conference and Exposition, 2000

${ }^{7}$ Freyne, S. F., "Academic Baseball: A Game of Active Learning," Proceedings of the ASEE Midwest Regional Annual Conference, Fayetteville, Arkansas, 2005

${ }^{8}$ Welch, R. W. and Klosky, J. L., "An Online Database and User Community for Physical Models in the Engineering Classroom," Advances in Engineering Education, Fall 2007

${ }^{9}$ Davis, J. S., "Strategic Planning for New Faculty: From What to How," Proceedings of the American Society for Engineering Education Annual Conference and Exposition, 2005

${ }^{10}$ www.asce.org/exceed

${ }^{11}$ Hale, W. M., Freyne, S. F., and Durham, S. A., "Discussions on Mentoring from a New Faculty Member's Perspective," Proceedings of the ASEE Annual Conference and Exposition, Pittsburgh, Pennsylvania, 2008 